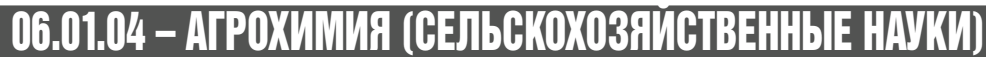

\section{ВЗАИМОДЕЙСТВИЕ МИКРОЭЛЕМЕНТОВ-СИНЕРГИСТОВ В РАЗЛИЧНЫХ СЕЛЬСКОХОЗЯЙСТВЕННЫХ РАСТЕНИЯХ ПРИ ОБРАБОТКЕ СЕМЯН И ЛИСТОВОЙ ПОДКОРМКЕ}

Костин Владимир Ильич, доктор сельскохозяйственных наук, профессор, заведующий кафедрой «Биология, химия, технология хранения и переработки продукции растениеводства» Дозоров Александр Владимирович, доктор сельскохозяйственных наук, профессор кафедры «Земледелие и растениеводство»

Исайчев Виталий Александрович, доктор сельскохозяйственных наук, профессор кафедры «Биология, химия, технология хранения и переработки продукции растениеводства»

ФГБОУ ВО УльянОвСКИЙ ГАУ

432017, г. Ульяновск, бульвар Новый Венец, 1; тел: +79063924220, bio-kafedra@yandex.ru

Ключевые слова: взаимодействие ионов, онтогенез, синергизм, аддитивность, урожайность, сахаристость, доброкачественность.

На базе выведенной нами формулы в многолетних исследованиях на различных сельскохозяйственных растениях изучались вопросы по взаимодействию микроэлементов d-семейства периодической системы Д.И. Менделеева и представителя р - семейства бора для сахарной свеклы. Установлено, что взаимодействие ионов способствует усилению продукционного процесса за счет повышения активности гидролитических и окислительно - восстановительных ферментов и механизмов регуляции растений, происходит усиление аттрагирующих процессов, результатом которых является активное набухание семян и поглощение ими воды. На яровой пшенице установлено, что сочетанное действие при обработке семян повышает темп водопотребления до 7 \%, интенсивность дыхания увеличивается на 26,1 - 29,9 \%, в результате усиливается активность фермента амилазы. Включается и трофическая регулячия и за счет взаимодействия микроэлементов растения полнее используют минеральные удобрения. Взаимодействие ионов не только усиливает физиолого - биохимические процессы в начале онтогенеза, а также включает регуляторные контуры, которые отражаются на отдаленном эффекте, результатом является повышение урожайности озимой, яровой пшеницы и сахарной свеклы, происходит также повышение качества сельскохозяйственной продукции, качества тех веществ, которые выработаны растением в течение эволюции.

\section{Введение}

Микроэлементы представляют собой группу незаменимых элементов, выполняющих очень важные функции в растительном организме. Они принимают участие в окислительно-восстановительных процессах, фотосинтезе, в метаболизме растений. Они являются кофакторами различных ферментов, повышают устойчивость к абиотическим факторам среды. Их недостаток вызывает ряд заболеваний.

Мы считаем, что при поступлении минеральных веществ, как макроэлементов, так и микроэлементов, происходит взаимное влия- ние, так как некоторые ионы сходной электронной конфигурации в пределах p- и d-семейств в периодической системе Д.И. Менделеева могут влиять на поглощение и транспорт других ионов.

Установлено, что одно- $\left(\mathrm{K}^{+}, \mathrm{Na}^{+}\right)$и двухвалентные катионы $\left(\mathrm{Ca}^{2+}\right)$ вызывают различные и даже противоположное физиологическое действия на цитоплазму. Ионы калия и натрия способствуют большей обводнённости цитоплазмы, а ионы кальция делают цитоплазму более вязкой, менее проницаемой $[1,2,3,6]$.

Из-за таких взаимодействий, называемых 

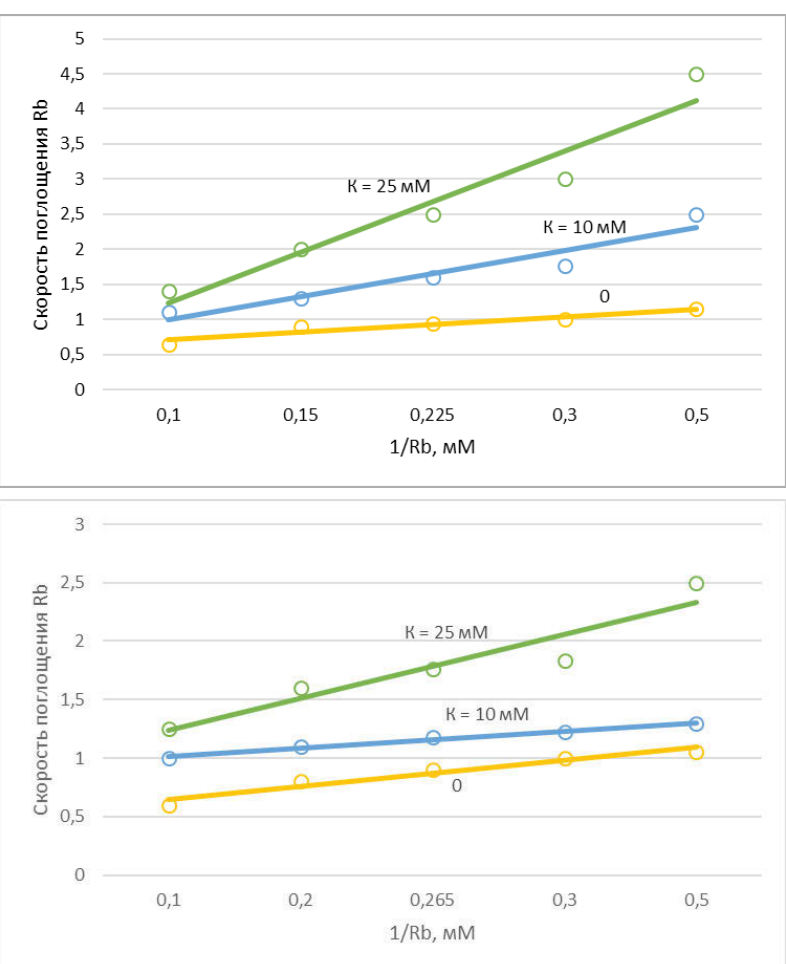

Рис. 1 - Конкурентное влияние $\mathrm{K}^{+}$и $\mathrm{Na}^{+}$на поглощение $\mathbf{R b}^{+.}$(no Epstein E., Hagen D.)

антагонизмом ионов, для корректировки дефицита отдельных минеральных веществ под растения обычно вносят смеси солевых растворов, а не отдельные соли.

Некоторые ионы могут влиять на поглощение и транспорт ионов (рис. 1).

На рис. 1 видно, что К ${ }^{+}$оказывает конкурентное влияние на поглощение $\mathrm{Rb}^{+}$, тогда как $\mathrm{Na}^{+}$проявляет лишь незначительный эффект.

А.Л. Курсанов [4] считает, что явление антагонизма ионов можно объяснить теорией клеточных переносчиков. Известно, что антагонизм ионов наблюдается при одновременной адсорбции различных ионов клеткой из почвенного раствора; поступление в клетку одного иона приводит к вытеснению из неё другого, что является результатом конкуренции веществ, поступающих в клетку.

В растениях наблюдается также синергизм и аддитивность в действии компонентов смеси минеральных солей. Синергетическое действие солей заключается в том, что одна из них усиливает действие другой.

По данным Д.А. Сабинина, внесение смеси азотно-фосфорных удобрений под хлопчатник превышает сумму прироста урожая, полученного от внесения отдельно фосфорных и азотных удобрений [5].

Отрицательный синергизм проявляется тогда, когда токсическое действие одной соли усиливается отравляющим действием другой.

Аддитивность - это действие смеси солевых растворов, которое равно сумме действия отдельных компонентов. Кроме положительного и отрицательного синергизма целесообразно ввести понятия абсолютный и относительный синергизм. Абсолютный синергизм, если эффект от суммы факторов выше действия изолирующих факторов, а если все показатели выше уровня контрольных растений и отдельно взятого фактора - относительный синергизм.

Объекты и методы исследований

Для изучения взаимодействия ионов более 30 лет проводятся лабораторные, полевые и производственные опыты на различных сельскохозяйственных культурах (озимая и яровая пшеница, горох, сахарная свёкла) только микроэлементами и в сочетании с регуляторами роста на некоторые физиологические процессы урожайности и качество продукции с обработкой семян для изучения начальных физиологических процессов и листовой подкормки. Почва опытного участка - чернозём выщелоченный среднемощный среднесуглинистый. Агрохимическая характеристика почвы: реакция среды в пахотном слое $\mathrm{pH}-5,89-6,50$, содержание гумуса 4,3-4,9\%, содержание подвижного фосфора $\left(\mathrm{P}_{2} \mathrm{O}_{5}\right)-1,05-1,50$ мг/кг, обменного калия - высокое 1,37-2,00 мг/кг почвы, сумма поглощённых оснований 25,5-27,8 мг-экв./100 г почвы.

Обеспеченность почвы используемыми микроэлементами низкая: молибденом - 0,10,2 мг/кг, марганцем - 25-40 мг/кг, цинком очень низкая 0,18-0,20 мг/кг и бором 0,1-0,18мг очень низкая.

Микроэлементы определяли на атомноабсорбционном спектрометре «Спектр-5-4», сахарозу на проточном поляриметрическом сахариметре АП-05, доброкачественность нормального сока в корнеплодах сахарной свёклы - в заводской лаборатории Ульяновского сахарного завода. Активность ферментов и других показателей - по общепринятым методикам и ГОСТам.

Наиболее эффективными на наш взгляд являются предпосевная обработка семян и листовая подкормка двумя, тремя элементами или факторами. Для оценки взаимодействия ионов и других факторов нами выведены и предложены эмпирические формулы:

Эф (ДФ $\Phi_{1}$ Д $\left.\Phi_{2}\right)>\ni \phi\left(Д \Phi_{1}+\right.$ ДФ $\left.{ }_{2}\right)$

где Эф - эффект от суммы факторов, Д доза (концентрация), ф- фактор.

Возможна ситуация, когда эффект при 
действии от доз (концентраций) изучаемых факторов сочетается следующим образом:

Эф (ДФ $\Phi_{1}$ ДФ $\left.{ }_{2}\right)=\ni \phi\left(Д \Phi_{1}+Д \Phi_{2}\right)$

Эф (ДФ $\times$ Х ДФ $)=\Phi_{1}\left(Д \Phi_{1}+\Phi_{2}\left(Д \Phi_{2}\right)-\Phi_{1}\right.$ $\left(Д \Phi_{1} \Phi_{2}\left(Д \Phi_{2}\right)\right)$

Как следует из 2-й формулы, в первом случае (2) факторы действуют аддитивно на уровне доз (концентраций), а во втором (3) независимо на уровне механизмов.

На основе трёх вышеуказанных формул выведена универсальная эмпирическая формула для определения коэффициента взаимодействия (синергизм):

$$
\mathrm{K}_{\mathrm{в} 3}=\frac{\sum Д \Phi-\left(Д_{1} \Phi_{1}+Д_{2} \Phi_{2}+\ldots+Д_{n} \Phi_{n}\right)}{\sum Д \Phi}
$$

где $\mathrm{K}_{\text {вз }}$ - коэффициент взаимодействия, $\Sigma$ - эффект от суммы факторов, Д - доза или концентрация используемого вещества, $\Phi_{1} \Phi_{2} \Phi_{3}-$ действие изолируемых (взятых каждый отдельно) факторов [8, 9].

\section{Результаты исследований}

В настоящее время в литературе нет объяснений по взаимодействию ионов на растения и тем более отсутствуют механизмы объяснения синергизма, антагонизма и аддитивности ионов, особенности явления синергизма, механизма действия и каких - либо эмпирических формул.

Мы считаем, что синергизм - основной показатель для определения оптимального питания и усиления метаболических процессов. Поэтому по данной эмпирической формуле можно определить синергизм действия по различным физиолого-биохимическим параметрам, урожайности и качества выращенной продукции.

В доступной литературе и в различных учебниках по физиологии растений , как правило, рассматривается только антагонизм одно- и двухвариантных ионов и указывается, что антагонизм зависит от валентности [10, 11, 12]. Мы считаем, следует учитывать строение электронных орбиталей $[13,14,15,16]$.

Следует учитывать также не только валентность используемого элемента, но и степень окисления, особенно для элементов пятой, шестой и седьмой групп. Эти элементы могут находиться в состоянии катиона и в состоянии аниона, в низшей степени окисления в состоянии катиона, высшей степени окисления - аниона. Например, $\mathrm{Mn}^{2+}$ - катион, а $\mathrm{MnO}_{4}^{-}-$анион. При нитратном азоте марганец действует как восстановитель, а при аммиачном - как сильный окислитель. Поэтому в этом плане необходимо учи- тывать не только катионное взаимодействие, но и катион-анионное.

Аналогичная картина и с молибденом: меняя валентность и степень окисления, он принимает участие в окислительно-восстановительных реакциях и является важным звеном в переносе электронов от окисленного субстрата к восстанавливающемуся веществу. Взаимодействие ионов способствует усилению продукционного процесса за счёт регуляции внутриклеточного, межклеточного и организменного взаимодействия, которые контролируются трофической, ферментативной, гормональной и электрофизиологической системами регуляции. За счёт этих процессов можно управлять продукционным процессом. По данным Н.Ф. Батыгина [7] , эти системы определяют функциональную активность ткани, а также воздействуют на клетки через внутриклеточные системы регуляции. Регуляция на организменном уровне осуществляется через центры организации, или доминирующие центры.

Для выяснения взаимодействия ионов (явления синергизма) и продукционного процесса нами составлена схема (рис. 2). Продукционный процесс в течение всего онтогенеза включает регуляторные контуры. В результате синергизма происходит активация окислительно-восстановительных ферментов, усиливаются аттрагирующие процессы, начинается более усиленное набухание семян и поглощение ими воды, в результате усиливаются метаболические процессы, которые выработаны в процессе эволюции для данного вида растений, и в качестве отдалённого эффекта происходит повышение урожайности и улучшение качества сельскохозяйственной продукции.

Наши исследования показывают, что обработка семян яровой пшеницы микроэлементами повышает темп водопоступления от 1,5 до 7\% по отношению к контролю, коэффициент синергизма по отношению к водопотреблению составляет в пределах 0,012-0,1. Нашими исследованиями (1994-1997 годы) [17] установлено, что микроэлементы марганец, молибден и в сочетании стимулируют ростовые процессы на начальных этапах прорастания яровой пшеницы, особенно при сочетании двух или трёх элементов, увеличивается интенсивность дыхания на 26,1-26,9\%. В результате увеличивается активность фермента амилазы ( $\alpha, \beta$ и $\alpha+\beta)$ (табл. 1).

Из результатов видно отсутствие отрицательного синергизма. Анализ данных таблицы 1 показывает, что под влиянием микроэлементов, 


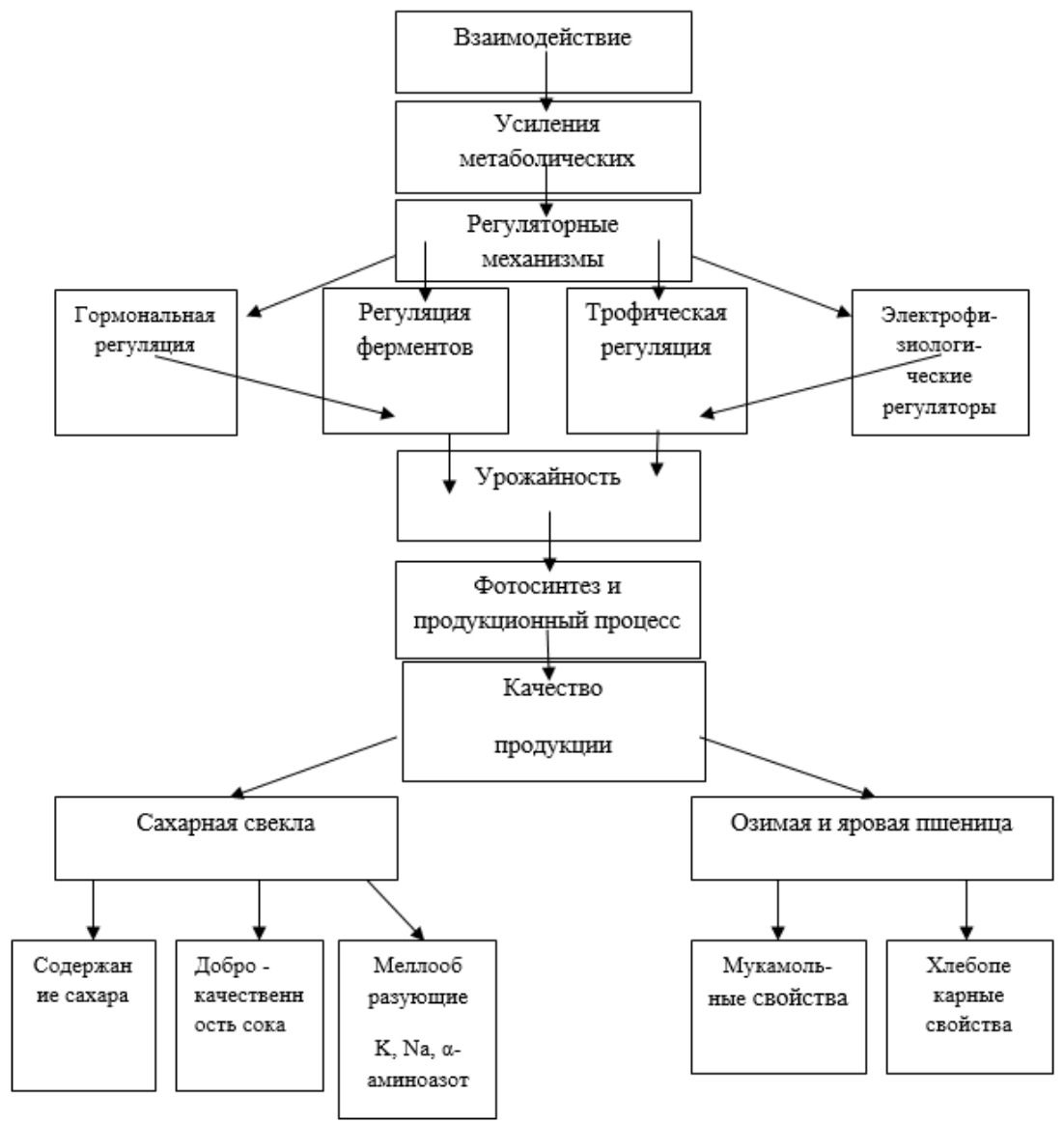

Рис. 2 - Схематическое изображение исследований для выяснения взаимодействия (явления синергизма) для различных сельскохозяйственных культур

Таблица 1

Влияние предпосевной обработки семян микроэлементами-синергистами на активность $\alpha$ - и $\beta$-амилаз при прорастании семян твёрдой пшеницы сорта Безенчукская 139, мг мальтозы на $100 \mathrm{Mr}$ зерна

\begin{tabular}{|c|c|c|c|c|c|}
\hline $\begin{array}{c}\text { Время } \\
\text { прора- } \\
\text { щивания } \\
\text { (сутки) }\end{array}$ & $\begin{array}{c}\text { Фер- } \\
\text { мент }\end{array}$ & Контроль & Мо & Mn & Мо + Mn \\
\cline { 3 - 6 } & $\alpha+\beta$ & $5,45 \pm 0,40$ & $7,54 \pm 0,45$ & $7,33 \pm 0,40$ & $8,80 \pm 0,60$ \\
\hline \multirow{4}{*}{2 суток } & $\alpha$ & $0,30 \pm 0,41$ & $0,63 \pm 0,35$ & $0,61 \pm 0,31$ & $0,91 \pm 0,51$ \\
\cline { 2 - 6 } & $\beta$ & $5,15 \pm 0,51$ & $6,91 \pm 0,41$ & $6,72 \pm 0,37$ & $7,89 \pm 0,41$ \\
\hline \multirow{4}{*}{3 суток } & $\alpha+\beta$ & $10,72 \pm 1,15$ & $14,65 \pm 1,14$ & $14,77 \pm 1,01$ & $16,38 \pm 1,31$ \\
\cline { 2 - 6 } & $\alpha$ & $1,57 \pm 0,91$ & $1,93 \pm 0,92$ & $1,90 \pm 0,91$ & $2,28 \pm 0,97$ \\
\cline { 2 - 6 } & $\beta$ & $9,15 \pm 1,01$ & $12,72 \pm 1,15$ & $12,87 \pm 1,10$ & $14,1 \pm 1,10$ \\
\hline \multirow{4}{*}{4 суток } & $\alpha+\beta$ & $24,67 \pm 3,1$ & $29,31 \pm 3,31$ & $31,41 \pm 3,15$ & $34,11 \pm 3,41$ \\
\cline { 2 - 6 } & $\alpha$ & $3,57 \pm 2,15$ & $5,31 \pm 2,11$ & $5,81 \pm 1,11$ & $6,31 \pm 1,64$ \\
\cline { 2 - 6 } & $\beta$ & $21,1 \pm 2,6$ & $23,4 \pm 2,71$ & $25,6 \pm 2,71$ & $27,8 \pm 2,74$ \\
\hline \multirow{3}{*}{5 суток } & $\alpha+\beta$ & $35,41 \pm 2,77$ & $47,41 \pm 3,1$ & $43,81 \pm 3,3$ & $48,22 \pm 3,41$ \\
\cline { 2 - 6 } & $\alpha$ & $4,31 \pm 2,7$ & $6,31 \pm 2,4$ & $6,11 \pm 2,81$ & $7,11 \pm 2,71$ \\
\cline { 2 - 6 } & $\beta$ & $31,1 \pm 3,0$ & $41,1 \pm 3,15$ & $37,7 \pm 3,21$ & $41,11 \pm 3,11$ \\
\hline \multirow{3}{*}{6 суток } & $\alpha+\beta$ & $30,3 \pm 1,18$ & $35,54 \pm 1,2$ & $36,11 \pm 1,6$ & $34,1 \pm 1,17$ \\
\cline { 2 - 6 } & $\alpha$ & $3,31 \pm 1,81$ & $5,11 \pm 1,77$ & $4,77 \pm 1,81$ & $5,11 \pm 1,91$ \\
\cline { 2 - 6 } & $\beta$ & $26,99 \pm 2,1$ & $30,43 \pm 1,81$ & $31,34 \pm 1,98$ & $28,99 \pm 1,81$ \\
\hline
\end{tabular}

особенно при сочетанном действии, увеличивает амилазную активность, что приводит к более высокой мобилизации питательных веществ и способствует более интенсивному переходу проростков к автотрофному питанию.

Аналогичная картина наблюдается в семенах мягкой яровой пшеницы Л-503 (табл. 2).

Результаты исследований показывают, что суммарная активность $\alpha-n$-амилаз имеет высокий коэффициент синергизма, за исключением 96 часа проращивания. Мы считаем, это связано с тем, что на четвёртые сутки происходит полный гидролиз крахмала на $\alpha$-D-глюкозу, это создаёт предпосылки более для интенсивного роста растений и переходу на автотрофный тип питания.

Обработка семян микроэлементами повышает активность и фермента каталазы, проявляющуюся с 12-ти часов набухания на 2,15-7,20\%, при этом по активности фермента наблюдается положительный синергизм, в результате аттрагирующего эффекта и усиления ферментативной активности происходит более интенсивное накопление массы проростков до $23,2 \%$ и корешков до $30,1 \%$, увеличивается общая и рабочая адсорбирующая поверхность корней яровой пшеницы (табл. 3).

По этим показателям микроэлементы показали типичный относительный синергизм.

По каталазе аналогичные данные получены в опытах 20082011 годов при использовании сульфата цинка и сульфата марганца с новым сортом яровой пшеницы Симбирцит (табл. 4).

Во всех случаях проявляется относительный синергизм за исключением марганца на 24 часе, где активность фермента в варианте сульфат марганца выше по сравнению с сочетанным вариан- 
Таблица 2

Влияние микроэлементов на суммарную $\alpha$ - и $\beta$-амилазы и коэффициенты синергизма в семенах яровой пшеницы Л-503 при прорастании, мг гидролизованного крахмала за 1 ч/1 г сухого вещества

\begin{tabular}{|c|c|c|c|c|c|c|}
\hline \multirow{2}{*}{ Вариант } & \multicolumn{6}{|c|}{ Время прорастания, ч } \\
\hline & 12 & 24 & 36 & 48 & 72 & 96 \\
\hline Контроль & $16,7 \pm 0,5$ & $21,5 \pm 0,45$ & $33,2 \pm 0,48$ & $52,0 \pm 0,71$ & $129,7 \pm 0,63$ & $72,0 \pm 0,82$ \\
\hline Mo & $17,5 \pm 0,49$ & $22,5 \pm 0,45$ & $34,2 \pm 0,48$ & $53,7 \pm 0,63$ & $132,2 \pm 0,84$ & $72,5 \pm 0,94$ \\
\hline $\mathrm{Mn}$ & $17,5 \pm 0,45$ & $22,7 \pm 0,48$ & $33,5 \pm 0,65$ & $52,5 \pm 0,87$ & $132,5 \pm 0,87$ & $72,2 \pm 0,83$ \\
\hline $\mathrm{Mo}+\mathrm{Mn}$ & $19,3 \pm 0,48$ & $25,0 \pm 0,41$ & $37,2 \pm 0,5$ & $56,2 \pm 0,48$ & $135,2 \pm 0,5$ & $66,0 \pm 0,71$ \\
\hline $\begin{array}{l}\text { Коэффициент } \\
\text { синергизма }\end{array}$ & 2 & 1,59 & 2,07 & 2,1 & 1,29 & $-0,9$ \\
\hline
\end{tabular}

Таблица 3

Адсорбирующая поверхность корней яровой пшеницы, см²

\begin{tabular}{|l|c|c|}
\hline Вариант & Общая адсорбирующая поверхность & Рабочая адсорбирующая поверхность \\
\hline Контроль & 564,48 & 275,32 \\
\hline Молибден & 648,77 & 319,47 \\
\hline Марганец & 678,13 & 344,93 \\
\hline Молибден + Марганец & 685,97 & 348,87 \\
\hline
\end{tabular}

Таблица 4

Активность каталазы в проростках яровой пшеницы (микромоль $\mathrm{H}_{2} \mathrm{O}_{2}$, разложившейся за 1 минуту в расчёте на 1 г сухого вещества)

\begin{tabular}{|l|c|c|c|c|c|}
\hline \multirow{2}{*}{\multicolumn{1}{c|}{ Вариант }} & \multicolumn{5}{|c|}{ Время прорастания, ч } \\
\cline { 2 - 6 } & 12 & 24 & 48 & 72 & 96 \\
\hline Контроль & $23,89 \pm 0,49$ & $34,51 \pm 0,26$ & $62,85 \pm 0,60$ & $91,11 \pm 0,71$ & $69,72 \pm 0,86$ \\
\hline Цинк & $24,83 \pm 0,43$ & $37,92 \pm 0,51$ & $66,18 \pm 0,60$ & $96,74 \pm 0,43$ & $71,81 \pm 0,94$ \\
\hline Марганец & $25,87 \pm 0,26$ & $39,44 \pm 0,35$ & $66,04 \pm 0,88$ & $97,57 \pm 0,87$ & $75,78 \pm 0,49$ \\
\hline Цинк + Марганец & $26,81 \pm 0,55$ & $38,75 \pm 0,17$ & $67,64 \pm 0,43$ & $99,51 \pm 0,10$ & $77,36 \pm 0,43$ \\
\hline
\end{tabular}

$\operatorname{TOM}(\mathrm{Zn}+\mathrm{Mn})$

Электрофизиологические процессы, повидимому, также играют роль в согласованности различных физиологических процессов в растительном организме, которые обеспечиваются системами регуляции. В растительном организме существуют электрические поля, которые влияют на жизнедеятельность клеток и тканей, как правило сопровождаются изменением электропотенциалов.

Предполагается, что под действием электрических полей в клеточных мембранах происходит латеральное перемещение заряженных липопротеиновых комплексов, выполняющих различные специализированные функции. Таким образом, следствием изменения микроструктуры электрических полей в тканях может быть перераспределение подвижных боковых компонентов в мембранах, в результате чего фиксируется новое физиологическое состояние клеток [18].

Мы считаем, что обработка семян или ли- стовая подкормка растений различными микроэлементами способствует образованию окислительно-восстановительных потенциалов, которые являются мерой соответствующего количества электрической энергии электронов. Таким образом, можно констатировать, что микроэлементы способствуют образованию в растительных клетках электрических потенциалов, а многие ионы необходимы как активаторы внутриклеточных синтезов, в том числе и самих ферментов.

Микроэлементы способствуют интенсивному поступлению макро- и микроэлементов в листья, репродуктивные органы, т.е. они включают и трофическую регуляцию и за счёт микроэлементов растения полнее используют минеральные удобрения.

Нами впервые был проведён расчёт коэффициентов взаимодействия активного штамма ризобий, марганца и молибдена на накопление микроэлементов [19]. Результаты исследований приведены в таблице 5.

Исследования показывают, что коэффи- 
Таблица 5

Коэффициенты взаимодействия между активным штаммом ризобий, марганцем и молибденом в онтогенезе гороха по накоплению микроэлементов, в среднем за 1992-1994 годы

\begin{tabular}{|c|c|c|c|c|c|c|c|}
\hline \multirow{2}{*}{ Фенологическая фаза } & \multicolumn{7}{|c|}{ Микроэлемент } \\
\hline & $\mathrm{Fe}$ & $\mathrm{Mn}$ & $\mathrm{Zn}$ & $\mathrm{Cu}$ & Co & $\mathrm{J}$ & Mo \\
\hline Всходы & 0,09 & 0,22 & $-0,46$ & 0,22 & 0 & 0 & 0,22 \\
\hline Стеблевание & 0,29 & 0,56 & 0,67 & $-0,43$ & 0, & 0 & 0,27 \\
\hline Бутонизация & $-0,14$ & $-0,10$ & 0,68 & $-0,40$ & 0,5 & 0,8 & 0,22 \\
\hline Цветение & 0,09 & 0,65 & 0,43 & 0 & 1,0 & 0,08 & 0,39 \\
\hline Налив семян (биомасса) & 0,18 & 0,27 & 0,50 & 0 & 0 & 0 & 0,43 \\
\hline Налив семян бобы & 0,73 & 0 & 0,31 & 0,57 & 0,33 & 1,0 & 0,44 \\
\hline Полная спелость (семена) & 0,62 & 0,13 & 0,23 & 0,29 & 0,20 & 0,27 & 0,33 \\
\hline
\end{tabular}

Таблица 6

Урожайность яровой пшеницы, т/га, сорт Симбирцит.

\begin{tabular}{|l|c|c|c|c|}
\hline \multicolumn{1}{|c|}{ Вариант } & 2009 & 2010 & 2011 & 2012 \\
\hline Контроль & 2,23 & 1,24 & 2,45 & 1,97 \\
\hline Молибден & 2,47 & 1,30 & 2,97 & 2,25 \\
\hline Марганец & 2,65 & 1,37 & 2,72 & 2,24 \\
\hline Молибден + Марганец & 2,57 & 1,38 & 3,16 & 2,37 \\
\hline \multicolumn{4}{|c}{ Приложение: опыт по предпосевной обра- }
\end{tabular}
ботке семян.

Таблица 7

Урожайность яровой пшеницы, т/га.

\begin{tabular}{|l|c|c|c|c|c|}
\hline \multicolumn{1}{|c|}{ Вариант } & 2014 & 2015 & 2016 & 2017 & $\begin{array}{c}\text { Средняя уро- } \\
\text { жайность }\end{array}$ \\
\hline Контроль & 4,39 & 1,90 & 4,32 & 4,10 & 3,68 \\
\hline Молибден & 4,94 & 2,43 & 5,54 & 4,52 & 4,42 \\
\hline Марганец & 5,00 & 2,44 & 5,43 & 4,36 & 4,29 \\
\hline $\begin{array}{l}\text { Молибден + } \\
\text { Марганец }\end{array}$ & 5,15 & 2,48 & 5,74 & 5,02 & 4,44 \\
\hline
\end{tabular}

Таблица 8

Коэффициент взаимодействия на основные показатели качества корнеплодов сахарной свеклы (2012-2014гг.)

\begin{tabular}{|l|c|c|c|c|}
\hline \multicolumn{1}{|c|}{ Вариант } & $\begin{array}{c}\text { Сахари- } \\
\text { стость, } \\
\%\end{array}$ & $\begin{array}{c}\text { Коэффи- } \\
\text { циент } \\
\text { взаимо- } \\
\text { действия }\end{array}$ & $\begin{array}{c}\text { Доброка- } \\
\text { чествен- } \\
\text { ность сока, } \\
\text { у.е. }\end{array}$ & $\begin{array}{c}\text { Коэффи- } \\
\text { циент } \\
\text { взаимо- } \\
\text { действия }\end{array}$ \\
\hline Контроль & 16,4 & - & 85,4 & - \\
\hline Бор & 16,8 & - & 86,3 & - \\
\hline Цинк & 16,5 & - & 85,7 & - \\
\hline Марганец & 16,5 & - & 85,8 & - \\
\hline $\begin{array}{l}\text { Цинк + Мар- } \\
\text { ганец }\end{array}$ & 16,8 & 0,5 & 86,2 & $+0,0125$ \\
\hline Цинк + Бор & 17,1 & 0,28 & 86,5 & $-0,009$ \\
\hline $\begin{array}{l}\text { Марганец + } \\
\text { Бор }\end{array}$ & 17,1 & 0,28 & 86,7 & 0 \\
\hline $\begin{array}{l}\text { Цинк + Мар- } \\
\text { ганец + Бор }\end{array}$ & 17,3 & 0,39 & 87,2 & 0,12 \\
\hline
\end{tabular}

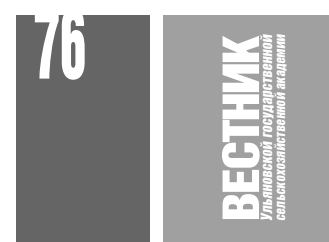

циенты взаимодействия по железу, марганцу и меди в фазу бутонизации, цинку - в фазу всходов и меди - в фазу стеблевания имеют отрицательный знак. Следовательно, в данном случае отрицательный антагонизм. В процентном отношении показатели содержания выше контроля, следовательно, в данном случае проявляется относительный синергизм. В 9-ти случаях проявляется сложение суммы эффектов, т.е. аддитивность. В остальных 33 случаях - типичный абсолютный синергизм.

Взаимодействие ионов не только усиливает физиолого-биохимические процессы в начале онтогенеза, а также включает регуляторные контуры, которые контролируют весь продукционный процесс, в результате увеличивается урожайность сельскохозяйственных растений, об этом свидетельствуют наши многолетние исследования последних лет на яровой, озимой пшенице и сахарной свекле (табл. 6, 7).

В среднем во всех случаях проявляется относительный синергизм за исключением $\mathrm{MnSO}_{4}$ в 2009 г., где проявляется отрицательный синергизм.

Аналогичные результаты получены в 20142017 гг. по обработке семян и внекорневой подкормке (табл. 7)

Во все года исследований проявляется относительный синергизм.

Четко проявляется явление абсолютного и относительного синергизма на технологических качествах корнеплодов сахарной свеклы (табл. 8).

Из полученных данных (табл. 8) видно, что по сахаристости во всех случаях проявляется абсолютный синергизм, по доброкачественности в двух случаях - абсолютный синергизм, в одном случае - аддитивность и относительный синергизм.

\section{Выводы}

Полученные результаты могут решить вопросы минерального питания растения, так как 
трудно переоценить роль взаимодействия ионов химических элементов. Они открывают возможность (перспективы) для регуляции поступления в растения макроэлементов. Улучшение минерального питания растений способствует усилению реутилизации азота и фосфора из вегетативных органов в репродуктивные.

Перечисленные регуляторные контуры, направленные на усиление фотосинтеза, обеспечивающего сохранение гомеостаза растений, позволяют управлять продукционным процессом для повышения урожайности и улучшения качества полученной продукции.

Взаимодействие ионов является сложным процессом, включающим не только их конкуренцию. Физиолого-биологические и регуляторные механизмы необходимо учитывать для рационального применения удобрений и микроэлементов в целях оптимизации минерального питания.

\section{Библиографический список}

1. Epstein, E. Plant Physiol. / E. Epstein, D. Hagen, 1952, 27 p 457-474.

2. Epstein, Emanuel. Mineral Nutrition of Plants: Principles and Perspectives / Emanuel Epstein, Arnold J. Bloom. 2 edition. - Sinauer Assocites, $2004-400$ p.

3. Гэлстон, А. Жизнь зеленого растения / А. Гэлстон, П. Дэвис, Р. Сэттер .- М.: «Мир» - 1983. $550 \mathrm{c.}$

4. Курсанов, Н.Л. Транспорт ассимилятов в растении / А.Л. Курсанов // - М.: Наука, 1976. $646 \mathrm{c}$

5. Сабинин, Д.А. Физиологические основы питания растений / Д.А. Сабинин. - М.: Изд-во АН СССР, 1965. - 512 с.

6. Власюк, П.А. Научные разработки по микроэлементам и перспективы развития в УССР и МССР / П.А. Власюк // Микроэлементы в окружающей среде. - Киев: Наукова Думка, 1980. - С. 5-13.

7. Батыгин, Н.Ф. Онтогенез высших растений / Н.Ф. Батыгин - М.: Агропромиздат, 1986. 102 c.

8. Костин, В.И. Элементы минерального питания и росторегуляторы в онтогенезе сельскохозяйственных культур / В.И. Костин, В.А. Исайчев, О.В. Костин - М.: Колос, 2006. - 290 с.

9. Костин, О.В. Взаимодействие ионов в сельскохозяйственных растениях / О.В. Костин, В.А. Исайчев, В.И. Костин // Вестник РАСХН. 2013. - №3. - С. 21-23.

10. Якушкина, Н.И. Антагонизм ионов / Н.И.
Якушкина, Е.Ю. Бахтенко //В кн. Физиология растений: учебник для студентов вузов.- М.: ВЛАДОС, 2004. - С. 218-220.

11. Гуральчук, Ж.С. Взаимодействие магния и цинка в питании и обмене веществ / Ж.С. Гуральчук, И.Н. Гуров // В кн. Физиологические основы повышения эффективности минерального питания растений. - Киев: Наукова Думка, 1987. - С. 84-89.

12. Охраменко, М.Ф. К вопросу о влиянии на растения сочетаний микроэлементов / М.Ф. Охраменко, Л.М. Кузьменко, А.А. Сивак // Сб.: Микроэлементы в обмене веществ и продуктивности растений. - Киев: Наукова Думка, 1984. - С. 16-20.

13. Kostin, V.I. Prospects of use of growth regulators of new generation and microelementssynergists in technology of cultivation of a sugar beet / V.I. Kostin, A.V. Dozorov, V.A. Isaychev, V.A. Oshkin // Proceedings of International scientific and technical Conference named after Leonardo da Vinci. №2. Berlin: Wissenschaftliche Welt e. V., 2014. - P. 41-50.

14. Костин, В.И. Синергетическое действие микроэлементов при внекорневой подкормке сахарной свёклы / В.И. Костин, В.А. Ошкин // Актуальные вопросы образования и науки: сборник научных трудов по материалам Международной научно-практической конференции 30 декабря 2013 г.: в 14 частях. - Тамбов: Издательство ТРОО «Бизнес-Наука-Общество», 2014. - Часть 4. - С. 81-82.

15. Костин, В.И. Эффективность нереутилизующихся микроэлементов в свеклосахарном производстве / В.И. Костин, В.А. Ошкин // Сахарная свёкла. - 2014. - №2. - С. 40-41.

16. Костин, В.И. Изучение взаимодействия микроэлементов и мелафена на технологические качества корнеплодов сахарной свёклы / В.И. Костин, В.А. Исайчев, В.А. Ошкин // Вестник Ульяновской государственной сельскохозяйственной академии. - 2014. - №4 (28). - С. 64-69.

17. Костин, В.И. Теоретические и практические аспекты предпосевной обработки семян сельскохозяйственных культур физическими и химическими факторами / В.И. Костин .- Ульяновск, 1998. - 120 с.

18. Полевой, В.В. Электрофизиологическая регуляция / В.В. Полевой // Физиология растений. Учебник.- М.: «Высшая школа», 1989. - С. 48-50.

19. Дозоров, А.В. Оптимизация продукционного процесса гороха и сои в условиях лесостепи Поволжья / А.В. Дозоров, О.В. Костин .- Ульяновск, 2003. - 166 с. 


\title{
INTERRELATIONSHIP OF MICROELEMENTS-SYNERGISTS OF VARIOUS AGRICULTURAL CROPS IN CASE OF TREATMENT OF SEEDS AND LEAF FERTILIZATION
}

\author{
Kostin V.I.,Dozorov A.V., Isaychev V.A. \\ FSBEI HE Ulyanovsk SAU \\ 432017, Ulyanovsk, Novyi Venets Boulevard, 1; Tel: +79063924220, bio-kafedra@yandex.ru
}

Key words: ion interaction, ontogenesis, synergism, additivity, yield, sugar content, high quality.

On the basis of the formula we derived, questions on the interaction of the trace elements of the d-family of D.I. Mendeleev periodic table system and a representative of the p-family (boron) for sugar beet were studied for many years on various agricultural plants. It has been established that the interaction of ions contributes to enhancement of the production process by increasing the activity of hydrolytic and redox enzymes and plant regulation mechanisms; there is an increase of the attracting processes, which results in active imbibition of seeds and their absorption of water. It was established on the example of spring wheat that the combined effect of seed treatment increases the water consumption rate to $7 \%$, the respiration rate increases by 26.1 - $29.9 \%$, as a result, the activity of the amylase enzyme increases. Trophic regulation is also activated and due to the interaction of microelements of the plant, mineral fertilizers are used more fully. The interaction of ions does not only enhance the physiological and biochemical processes at the beginning of ontogenesis, but also includes regulatory contours, which affects the long-term effect, the result is an increase of yield of winter, spring wheat and sugar beet, there is also an increase in the quality of agricultural products, the quality of those substances that are produced by plants during evolution.

Bibliography

1. Epstein, E. Plant Physiol. / E. Epstein, D. Hagen, 1952, 27 p 457-474.

2. Epstein, Emanuel. Mineral Nutrition of Plants: Principles and Perspectives / Emanuel Epstein, Arnold J. Bloom. 2 edition. - Sinauer Assocites, 2004 - 400 p.

3. Galston, A. Life of a green plant / A. Galston, P. Davis, R. Satter / Moscow. Mir - 1983. - $550 p$.

4. Kursanov, N.L. Transport of assimilates in a plant / A.L. Kursanov // - M .: Nauka, 1976. - 646

5. Sabinin, D.A. Physiological basis of plant nutrition /D. A. Sabinin. - M .: Publishing House of the Academy of Sciences of the USSR, 1965. - 512 $p$.

6. Vlasyuk, P.A. Scientific developments on trace elements and development prospects in the Ukrainian SSR and MSSR / P.A. Vlasyuk // Trace elements in the environment. - Kiev: Naukova Dumka, 1980. -P. 5-13.

7. Batygin, N.F. Ontogenesis of higher plants / N.F. Batygin // M .: Agropromizdat, 1986. - $102 p$

8. Kostin, V.I. Elements of mineral nutrition and growth regulators in the ontogenesis of crops / V.I. Kostin, V.A. Isaychev, O.V. Kostin / M .: Kolos, 2006. - 290 p.

9. Kostin, O.V. The interaction of ions in agricultural plants /O.V. Kostin, V.A. Isaychev, V.I. Kostin //Vestnik of the Russian Academy of Agricultural Sciences. 2013. - №3. - P. 21-23.

10. Yakushkina, N.I. Ion antagonism / N.I. Yakushkina, E.Yu. Bakhtenko / Plant Physiology for university students. M .: VLADOS, 2004. - P. 218-220.

11. Guralchuk,Zh.S. The interaction of magnesium and zinc in nutrrition and metabolism /Zh.S. Guralchuk, I.N. Gurov //In the book Physiological basis for improving the efficiency of mineral nutrition of plants. - Kiev: Naukova Dumka, 1987. - P. 84-89.

12. Okhramenko, M.F. On the effect of combination of trace elements on plants /M.F. Okhramenko, L.M. Kuzmenko, A.A. Sivak // - Digest: Trace elements in plant metabolism and productivity. - Kiev: Naukova Dumka, 1984. - P. 16-20.

13. Kostin, V.I. Prospects of use of growth regulators of new generation and microelements-synergists in technology of cultivation of a sugar beet / V.I. Kostin, A.V. Dozorov, V.A. Isaychev, V.A. Oshkin // Proceedings of International scientific and technical Conference named after Leonardo da Vinci. No2. - Berlin: Wissenschaftliche Welt e. V., 2014. - P. 41-50.

14. Kostin, V.I. Synergistic effect of microelements with foliar feeding of sugar beet /V.I. Kostin, V.A. Oshkin // Currant issues of education and science: a collection of scientific papers based on the materials of the International Scientific and Practical Conference on December 30 ${ }^{\text {th }}, 2013$ : in 14 parts. - Tambov: Publishing house Business-Science-Society public organization, 2014. - Part 4. - P. 81-82.

15. Kostin, V.I. The effectiveness of non-reutilized microelements of sugar beet production / V.I. Kostin, V.A. Oshkin // Sugar beet. - 2014. - No 2. - P. 40-41.

16. Kostin, V.I. Studying the interaction of microelements and melafen on the technological qualities of sugar beet root / V.I. Kostin, V.A. Isaychev, V.A. Oshkin // Vestnik of Ulyanovsk State Agricultural Academy. - 2014. - №4 (28). -P. 64-69.

17. Kostin, V.I. Theoretical and practical aspects of pre-sowing seed treatment of agricultural crops by physical and chemical factors / V.I. Kostin // Ulyanovsk, 1998. - 120 p.

18. Polevoy, V.V. Electrophysiological regulation / V.V. Polevoy // Plant Physiology. Textbook. M .: "High School", 1989. - P. 48-50.

19. Dozorov, A.V. Improvement of the production process of peas and soybean in the conditions of the forest-steppe of the Volga region / A.V. Dozorov, O.V. Kostin. - Ulyanovsk, 2003. - 166 p. 